\title{
Eosinophils as a Direct Target of the Anti-Inflammatory Effect of Salmeterol: Demonstration with Indium-111-Labeled Eosinophils
}

\author{
C.I. Ezeamuzie ${ }^{a} \quad$ G. Ziada ${ }^{b} \quad$ M. Mathew ${ }^{b} \quad$ E. Philips ${ }^{a} \quad$ S. Gopinath ${ }^{b}$ \\ A. Owunwanne ${ }^{b}$
}

Departments of a Pharmacology and Toxicology and b Nuclear Medicine, Faculty of Medicine, Health Sciences Centre, Kuwait University, Kuwait

\section{Key Words}

Eosinophils · Guinea pig · Salmeterol · Indium-111 · Skin treatment of ${ }^{111}$ In-eosinophils with salmeterol $(1 \mu M)-a$ concentration giving about $65 \%$ inhibition of in vitro adherence - had no effect on the basal (PBS-induced) skin accumulation of the injected cells. However, it inhibited the net accumulation induced by OA $(0.01-1 \mu \mathrm{g} / \mathrm{site})$ and PAF (0.01-1 nmol/site) by 58.8-100\%. At $1 \mu M$, salmeterol itself had no significant effect on the viability and circulation of ${ }^{111}$ In-eosinophils. Conclusion: These results provide evidence for a direct inhibitory effect of salmeterol on eosinophils and suggest that this may account for a significant part of its clinical anti-inflammatory properties.

Copyright @ 2001 S. Karger AG, Basel

\section{Introduction}

Eosinophil accumulation in tissues is the hallmark of allergic diseases such as asthma, allergic rhinitis and atopic dermatitis [1, 2], and several studies have emphasized the crucial roles these cells play in the pathophysiology of the diseases $[3,4]$. Activated eosinophils release several cationic proteins such as the major basic protein, eosinophil cationic protein, eosinophil-derived neurotoxin and eosinophil peroxidase, which are directly toxic to many tissues [5]. In asthma, for example, it has been suggested

\begin{tabular}{ll}
\hline KARGER & ( ) 2001 S. Karger AG, Basel \\
Fax +4161306 1234 & 1011-7571/01/0102-0083\$17.50/0 \\
$\begin{array}{l}\text { E-Mail karger@karger.ch } \\
\text { www.karger.com }\end{array}$ & $\begin{array}{l}\text { Accessible online at: } \\
\text { www.karger.com/journals/mpp }\end{array}$
\end{tabular}

Dr. Charles I. Ezeamuzie

Department of Pharmacology and Toxicology, Faculty of Medicine

Health Sciences Centre, Kuwait University, PO Box 24923

Safat 13110 (Kuwait)

Fax +965 531 8454, E-Mail ezeamuzie@hsc.kuniv.edu.kw 
that the release of these substances in the bronchial tissues orchestrate further inflammation that leads to the desquamation of bronchial epithelium and the subsequent bronchial hyperreactivity $[6,7]$. Thus, the ability to inhibit allergen-induced eosinophilic inflammation is now regarded as an important property required of a good antiallergic or anti-asthma drug [8].

Salmeterol is along-acting $\beta_{2}$-adrenoceptor agonist that is employed as a bronchodilator in the treatment of bronchial asthma. Apart from the prolonged bronchodilation in provides, its effectiveness in asthma also appears to stem from its possession of significant anti-inflammatory effects. Systemic administration of salmeterol, but not the conventional shorter-acting $\beta_{2}$-adrenoceptor agonists salbutamol, has been reported to suppress allergen- and mediator-induced bronchial or skin eosinophil recruitment in sensitized guinea pigs [9, 10]. A similar effect against allergen-induced late-phase responses and bronchial hyperreactivity has also been reported in asthmatics $[11,12]$.

The in vivo mechanism of such anti-inflammatory effects is still uncertain, but often attributed to the possible inhibition of T-cell generation of eosinophil-chemotactic cytokines, especially interleukin 5 (IL-5) and granulocyte macrophage colony-stimulating factor (GM-CSF) [13]. However, since eosinophils are known to possess $\beta_{2^{-}}$ adrenoceptors [14, 15] and that salmeterol can inhibit eosinophil activation in vitro [16-18], a direct inhibition of the eosinophils themselves could also be a possible in vivo mechanism.

The purpose of this study was, therefore, to determine whether eosinophils themselves are a target of the inhibitory effect of salmeterol in vivo, especially when eosinophilic inflammation is induced by an allergen.

\section{Materials and Methods}

\section{Immunization of Guinea Pigs}

Male Dunkin-Hartley guinea pigs (250-300 g) were actively immunized by an intraperitoneal injection of $1 \mathrm{ml}$ of a mixture containing $10 \mu \mathrm{g}$ ovalbumin (OA) and $5 \mathrm{mg}$ aluminum hydroxide gel in saline. This injection was repeated after 7 days and between days 21 and 28 after the first injection; the animals were used for the experiments on allergen-induced eosinophilic skin inflammation.

Induction and Purification of Guinea Pig Peritoneal Eosinophils

Peritoneal eosinophilia was induced in male guinea pigs (400$450 \mathrm{~g}$ ) by repeated intraperitoneal injection (twice weekly for a total of 4-6 injections) of $0.5 \mathrm{ml}$ of horse serum. Peritoneal lavage was then performed with $5 \times 10 \mathrm{ml} \mathrm{Ca}^{2+}$ - and $\mathrm{Mg}^{2+}$-free Hank's balanced salt solution (HBSS), $\mathrm{pH}=7.4$, containing sodium citrate $(13 \mathrm{mM})$ and $0.3 \%$ bovine serum albumin (BSA). Cells were recovered by cen- trifugation, washed once in the same buffer, and resuspended at a concentration of $10^{7}$ cells $/ \mathrm{ml}$ for purification.

Eosinophils were purified by gradient centrifugation over Percoll (densities: $1.080,1.085$, and $1.090 \mathrm{~g} / \mathrm{ml}$ ). After centrifugation at $900 \mathrm{~g}$ on Beckman (GS-6R) centrifuge for $20 \mathrm{~min}$ at room temperature, eosinophils were collected as pellets. After hypotonic lysis of the contaminating erythrocytes, the eosinophils were washed twice and resuspended in the reaction buffer (HBSS containing $2 \mathrm{mMCa}^{2+}$ and $1 \mathrm{mM} \mathrm{Mg}^{2+}, \mathrm{pH}=7.4$ ) for adherence experiments or in phosphatebuffered saline (PBS) for ${ }^{111} \mathrm{In}$ oxine labeling. Eosinophil preparations of greater than $95 \%$ purity were used and the viability (determined by trypan blue exclusion) always exceeded $98 \%$.

\section{Measurement of Eosinophil Adherence in vitro}

Peritoneal eosinophils purified from horse serum-treated guinea pigs were resuspended at a concentration of $5 \times 10^{5} \mathrm{cells} / \mathrm{ml}$ in the reaction buffer. Fifty-microliter aliquots were then added to each well of a 96-well plate (Maxisorp, Nunc, Roskilde, Denmark) and incubated for $15 \mathrm{~min}$ with salmeterol or vehicle before stimulating adherence with platelet-activating factor (PAF) $(0.001-10 \mu M)$. After incubation for $30 \mathrm{~min}$ the plate was then washed 3 times with PBS (200 $\mu \mathrm{l} /$ well) at room temperature and the adherent cells lysed with $150 \mu 1$ of $0.1 \%$ Triton X-100. Fifty-microliter aliquots were then taken for the measurement of eosinophil peroxidase (EPO) activity by the $o$-phenylenediamine method [19]. The EPO in adhered cells as a percentage of the amount in the total cells added represented the percentage cell adherence [20].

\section{Labeling of Eosinophils and the Measurement of ${ }^{111}$ In-Labeled}

Eosinophils in Guinea Pig Skin

Purified eosinophils were labeled by incubating $2 \times 10^{7}$ cells (in $1 \mathrm{ml}$ PBS $)$ with ${ }^{111}$ In oxine $(100 \mu \mathrm{Ci}$ in $10 \mu \mathrm{l})$ for $15 \mathrm{~min}$ at room temperature. The labeled cells were washed twice and subsequently incubated for 10 min with salmeterol $(1 \mu M)$ or drug vehicle (dimethylsulfoxide (DMSO) diluted in buffer). After two further washes, the cells were finally resuspended at a concentration of $5 \times 10^{6}$ cells/ $\mathrm{ml}$ in PBS. Five million ${ }^{111}$ In-eosinophils $\left(1.5-2.0 \times 10^{7}\right.$ counts per minute (CPM)) were then injected intravenously into each OAimmunized guinea pig, under pentobarbitone anesthesia $(30 \mathrm{mg} / \mathrm{kg}$ i.p.). In experiments to evaluate the influence of drug treatment of ${ }^{111}$ In-eosinophils on their subsequent circulation in vivo, $400 \mu \mathrm{l}$ of venous blood was withdrawn at intervals after their injection and the radioactivity counted. The percentage of circulating ${ }^{111}$ In-eosinophils at each point in time was determined according to the following formula (assuming blood volume of $70 \mathrm{ml} / \mathrm{kg}$ body weight):

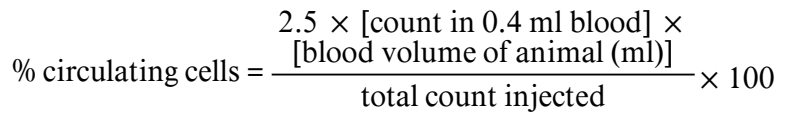

For experiments on skin accumulation of ${ }^{111} \mathrm{In}$-eosinophils, the intravenous injection of the cells was followed 10 min later by intradermal injection of $100 \mu \mathrm{l}$ of various concentrations of OA and PAF or saline in the dorsal shaved skin in a randomized site plan. After $4 \mathrm{~h}$ the animals were killed, the skin removed, cleaned of subcutaneous tissues and the injected sites $(10 \mathrm{~mm}$ diameter) punched out. The radioactivity of the samples as an index of accumulated ${ }^{111} \mathrm{In}$-eosinophils was then determined in a Packard Cobra II, well-type $\gamma$ counter, adjusted to include both $171-$ and $245-\mathrm{keV} \gamma$ energies. The number of eosinophils infiltrating the injected sites was then calculated by dividing the sample count with the count per injected cell (usually 


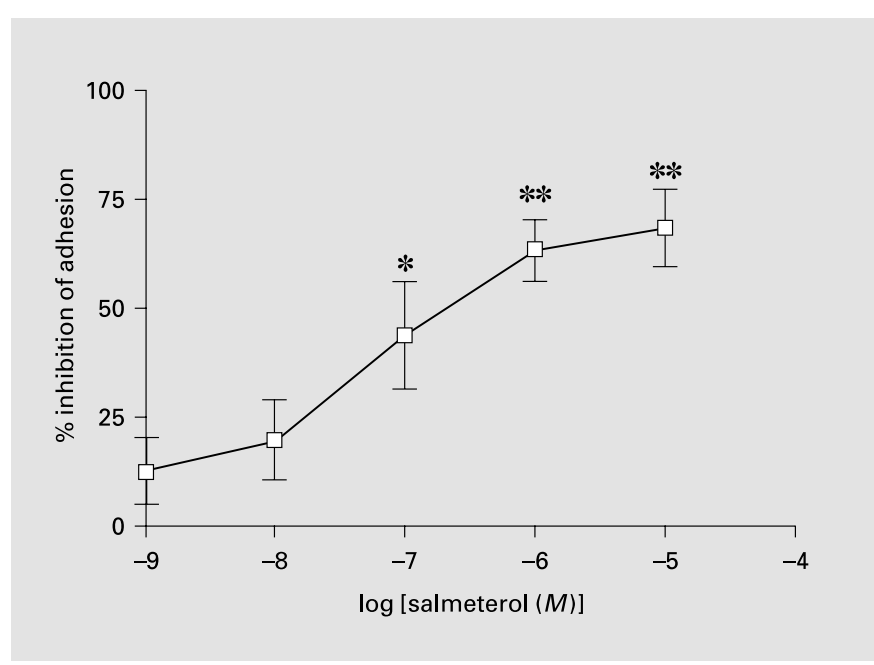

Fig. 1. Inhibition by salmeterol of the in vitro adherence of guinea pig eosinophils to plastic plates. Adherence was induced with $1 \mu M$ PAF and the mean net uninhibited adherence was $23.6 \pm 5.7 \%$ of the total cells added. Spontaneous adherence was always less than $5 \%$. Values are mean net percentage inhibition of adherence \pm standard deviation, $\mathrm{n}=4 . * \mathrm{p}<0.05 ; * * \mathrm{p}<0.01$.

2.8-7.0 CPM). Preliminary data showed that circulating non-eosinophil-associated radioactivity during $4 \mathrm{~h}$ of the experiment was less than $1 \%$; consequently, no correction was made to subsequent experimental data.

\section{Reagents}

The following reagents were obtained from Sigma Chemical Co., St. Louis, Mo., USA: Horse serum, BSA, HBSS, OA, trypan blue, DMSO, $o$-phenylenediamine, PAF and all the inorganic salts. ${ }^{111} \mathrm{In}$ oxine was obtained from Amersham PLC, UK, while salmeterol was a generous gift of Glaxo Welcome, PLC Greenford, Middx, UK.

\section{Statistics}

Values are given as means \pm standard deviation for the number (n) of independent experiments. The concentration producing $50 \%$ inhibition of adhesion was calculated by the non-linear regression analysis using GraphPad InPlot (GraphPad Software Inc., USA): Statistical significance was determined by the paired or unpaired ttests as appropriate. For multiple comparisons, one-way analysis of variance (ANOVA) was applied, followed by Dunnet's multiple comparison test. A p value $<0.05$ was considered significant.

\section{Results}

\section{Effect of Salmeterol on Eosinophil Adherence to}

\section{Plastic Plate}

In order to determine the appropriate concentration of salmeterol to be used for pre-treating ${ }^{111}$ In-eosinophils before injection into guinea pigs, the effect of different

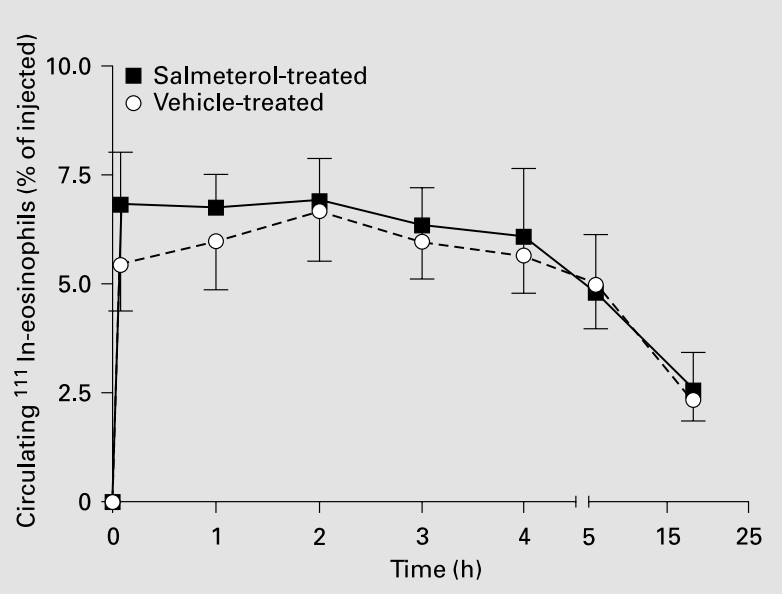

Fig. 2. Time course of the circulation of ${ }^{111} \mathrm{In}$-eosinophils after intravenous injection in guinea pigs. Labeled cells were pretreated for 15 min with salmeterol $(1 \mu M)$ or vehicle and washed twice before injection. Values are means \pm standard deviation, $\mathrm{n}=5$ in each case.

concentrations of the drug on PAF-induced adherence of eosinophils to plastic plates was studied. As shown in figure 1, salmeterol produced a concentration-dependent inhibition of PAF-induced adherence. The concentration that achieved $50 \%$ inhibition $\left(\mathrm{IC}_{50}\right.$ value) was $0.4 \mu \mathrm{M}$. The concentration of $1 \mu M$, which inhibited adherence by approximately $65 \%$ but without any significant toxicity (as judged by trypan blue exclusion), was chosen for the subsequent in vivo experiments.

\section{Effect of in vitro Pre-Treatment of ${ }^{111}$ In-Eosinophil with Salmeterol on Their Subsequent Circulation in vivo}

In order to study how the pre-treatment of ${ }^{111} \mathrm{In}$-eosinophils with salmeterol would affect their subsequent accumulation in the skin, it was necessary to first assess the effect of such treatment on eosinophil circulation per se. As shown in figure 2, when immunized guinea pigs were injected intravenously with vehicle-treated (and twice washed) ${ }^{111}$ In-eosinophils, approximately $6 \%$ of the injected cells were circulating $10 \mathrm{~min}$ after the injection. This level of circulating cells remained relatively steady for $4 \mathrm{~h}$. When ${ }^{111}$ In-eosinophils were pre-treated with salmeterol $(1 \mu M)$ and washed twice before injection, there was no significant difference in the level of circulating labeled cells at all time points studied. However, a slightly higher percentage of the injected cells were circulating in 


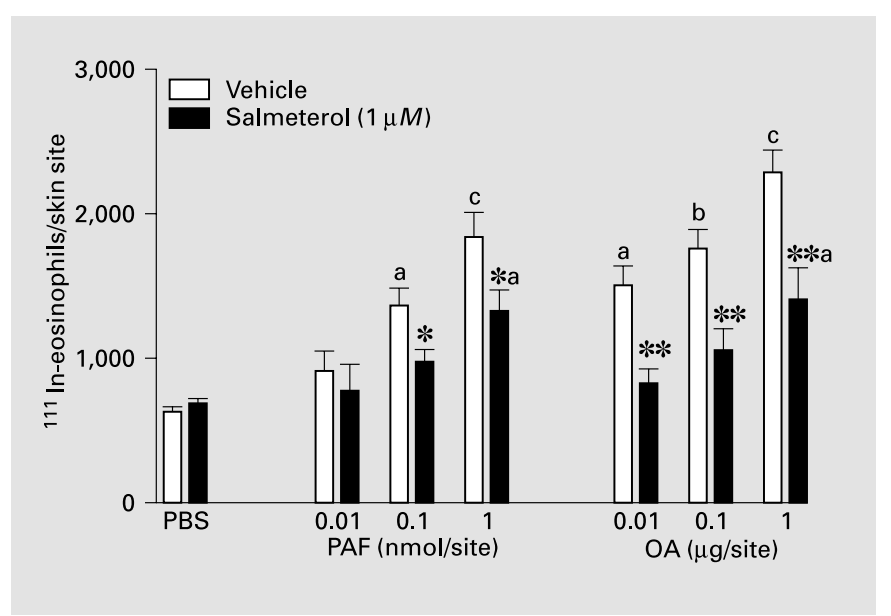

Fig. 3. The effect of in vitro pretreatment of ${ }^{111} \mathrm{In}$-eosinophils with salmeterol or vehicle on their subsequent skin accumulation in OAimmunized guinea pigs in response to intradermal injection of various concentrations of OA, PAF or PBS. Labeled cells were pretreated for 10 min with salmeterol $(1 \mu M)$ or vehicle and washed twice before injection intravenously into the animals. Values are means \pm standard deviation, $\mathrm{n}=5$ for vehicle and 6 for salmeterol. ${ }^{\mathrm{a}} \mathrm{p}<0.05,{ }^{\mathrm{b}} \mathrm{p}<0.01,{ }^{\mathrm{c}} \mathrm{p}<0.001$ (compared with PBS-injected site, by ANOVA followed by Dunnet's test). ${ }^{*} \mathrm{p}<0.05,{ }^{* *} \mathrm{p}<0.01$ (compared with corresponding vehicle-pretreated, by t-test).

the first $1 \mathrm{~h}$ after injection. Imaging of the whole animal showed that the bulk of the injected radioactivity was localized in the liver within the first $10 \mathrm{~min}$ and later in the spleen as well (data not shown).

\section{Effect of in vitro Pre-Treatment of ${ }^{111}$ In-Eosinophils with Salmeterol on Their Subsequent Skin Accumulation in vivo}

In animals given vehicle-treated ${ }^{111} \mathrm{In}$-eosinophils, PAF (0.01-1.0 nmol/site) and OA (0.01-1.0 $\mu \mathrm{g} / \mathrm{site})$ induced dose-dependent accumulation of the labeled cells in the skin. Compared with PBS-injected sites, the two highest concentrations of PAF and all concentrations of OA produced statistically significant increases of ${ }^{111} \mathrm{In}$ eosinophil accumulation $(\mathrm{p}<0.05-0.01)$ (fig. 3$)$. At the highest concentrations of $\mathrm{PAF}$ and $\mathrm{OA}$, the increases were 2.9-fold ( $1,850 \pm 371$ vs. $630 \pm 84$ cells/skin site), and 3.6 -fold ( $2,293 \pm 384$ vs. $630 \pm 84$ cells/skin site), respectively, $\mathrm{p}<0.01$ in both cases.

Pre-treatment of eosinophils with salmeterol $(1 \mu M)$ had no significant effect on the background accumulation of ${ }^{111}$ In-eosinophils at PBS-injected sites, but significantly reduced the accumulation at the sites injected with PAF or OA. For example, at the sites injected with the highest concentration of PAF ( $1 \mathrm{nmol} / \mathrm{site}),{ }^{111}$ In-eosinophil accumulation was reduced from $1,850 \pm 371 /$ skin site for vehicle-treated cells to $1,316 \pm 339$ /skin site for salmeterol-treated cells, $\mathrm{p}<0.05, \mathrm{n}=5-6$ (fig. 3 ). For the highest concentration of $\mathrm{OA}$, the corresponding values were 2,293 \pm 384 /skin site for vehicle-treated and 1,416 \pm 472 /skin site for salmeterol-treated cells, $\mathrm{p}<0.01$. Thus, salmeterol appeared to be slightly more effective in inhibiting OAinduced than PAF-induced ${ }^{111}$ In-eosinophil accumulation. When the net accumulation was considered, salmeterol almost completely abolished the effect of the two lower concentrations of both PAF and OA. At the highest concentration of PAF, salmeterol achieved a reduction of $58.0 \pm 5.2 \%$ while for $\mathrm{OA}$ it was $69.1 \pm 8.1 \%$.

\section{Discussion}

Previous reports have shown that salmeterol possesses in vivo anti-inflammatory effects in animal models of late allergic reactions and in human allergic diseases [9-12]. However, the cellular target of this action has remained uncertain. To determine if eosinophils are a target of this action, we have employed the guinea pig model of allergic skin inflammation. In this model, the injection of antigen into the skin of a previously immunized animal resulted in a skin reaction with heavy eosinophilic infiltration. The use of ${ }^{111}$ In-eosinophils allowed for precise quantitation of eosinophils infiltrating the sites of allergic skin reaction. The results obtained clearly showed that when ${ }^{111} \mathrm{In}$ eosinophils were pre-treated in vitro with salmeterol, washed and then injected intravenously into immunized animals, the ability of the cells to accumulate at allergenchallenged skin sites was either completely abolished or significantly reduced. A similar effect was also seen if skin reaction was induced with the eosinophil chemotactic factor PAF. These results therefore show that salmeterol can act directly on eosinophils to inhibit their ability to respond to chemotactic stimuli generated by the antigenantibody interaction. In the only other similar study, Teixiera and Hellewell [21] recently reported similar results although they employed only soluble mediators and zymosan-activated plasma. Thus, the present results represent the first demonstration of the effect of salmeterol against eosinophil accumulation induced by antigenantibody interaction.

In experiments of this nature, it is often crucial to ensure that neither the labeling of the cells nor their treatment with the drug affected their ability to circulate and function normally in vivo. It is also important to ensure 
that experiments are performed during a steady-state circulation of the injected cells. Previous studies have shown that guinea pigs labeled with ${ }^{111}$ In oxine fully retained viability as well as their in vivo responsiveness to various stimuli $[22,23]$. In the present experiments, we first studied the concentration-dependent inhibition of eosinophil adherence in vitro and on the basis of the results, the concentration of $1 \mu M$ salmeterol, which produced about $65 \%$ inhibition of adherence while having no effect on cell viability, was chosen for the subsequent in vivo experiments. Next we verified that ${ }^{111}$ In-eosinophils could circulate long enough for the in vivo experiments to be performed. Although only about $6 \%$ of the injected eosinophils were circulating $10 \mathrm{~min}$ after injection, this level remained relatively constant over the next $4 \mathrm{~h}-$ a sufficient time for the subsequent experiments. Whole body imaging (data not shown) showed that the bulk of the injected radioactivity was trapped in the liver and spleen soon after injection. The reason for this enhanced trapping is unclear, but may be a consequence of the purification/washing processes or the fact that the cells were derived from the peritoneum rather than the blood. A similar rapid extravasation of purified guinea pig ${ }^{111} \mathrm{In}$ eosinophils has been previously reported [21, 24]. Finally, it was verified that the pre-treatment of ${ }^{111}$ In-eosinophils with the chosen concentration of salmeterol did not significantly affect their subsequent circulation in vivo. This excluded the possibility that the inhibition of skin accumulation noted with salmeterol-treated ${ }^{111}$ In-eosinophils was a result of a lower number of circulating cells. On the contrary, there was a small early transient increase in the percentage of salmeterol-treated cells circulating compared with the vehicle-treated cells.

When salmeterol is given systemically, its ability to inhibit allergen-induced eosinophil infiltration into tissues is likely to result from at least two mechanisms. Firstly, it could act indirectly by inhibiting the release of eosinophil chemotactic factors (e.g., PAF, IL-5 and C5a) generated by a variety of pro-inflammatory cells as a consequence of the antigen-antibody interaction. The drug can do this by activating the $\beta_{2}$-receptors present on most inflammatory cells. The second mechanism, which the present study suggests, is that the drug acts directly on eosinophils preventing them from responding to the endogenously generated chemotactic stimuli. Although the exact biochemical effect of salmeterol on eosinophils was not specifically sought in the current study, it is known that eosinophils of guinea pigs and humans possess functional $\beta_{2}$-adrenoceptors on their surfaces $[14,15]$. The activation of these receptors by salmeterol would be expected to cause an increase in the intracellular levels of adenosine $3^{\prime}, 5^{\prime}$-cyclic monophosphate (cAMP) - a powerful inhibitor of leukocyte responses [17,25]. Thus, in view of the current and previous data [18], it is likely that the inhibition of adherence is crucial to the observed reduction in the in vivo cellular infiltration. Adherence to the vascular endothelium is the first step in the process of exvasation of blood leukocytes into tissues. A direct inhibition by salmeterol of the ability of eosinophils to adhere, perhaps as a result of the down-regulation of the expression of surface adhesion molecules (e.g. VLA4 and CD11/ CD18), may underlie the reduced skin accumulation by these cells.

\section{Conclusion}

The in vitro treatment of eosinophils with salmeterol strongly reduced their ability to accumulate in the skin in response to both antigen-antibody interaction and to a direct chemoattractant - PAF. This provides evidence for a direct inhibitory effect of salmeterol on eosinophils and suggests that this may account for a significant part of its clinical anti-inflammatory property. The exact mechanism remains unclear but may likely involve the inhibition of the ability of eosinophils to adhere to the vascular endothelium in the process of extravasation. 


\section{References}

1 Kay AB: Eosinophils as effector cells in immunity and hypersensitivity disorders. Clin Exp Immunol 1985;62:1-12.

2 Weller PF: The immunobiology of eosinophils. N Engl J Med 1991;324:1110-1118.

3 Frigas E, Gleich G: The eosinophils and the pathophysiology of asthma. J Allergy Clin Immunol 1986;77:527-537.

4 Barnes P: New concepts in the pathogenesis of bronchial hyperresponsiveness and asthma. J Allergy Clin Immunol 1989;83:1013-1026.

5 Gleich GJ, Adolphson CR: The eosinophil leukocyte: Structure and function. Adv Immunol 1986;39:177-253.

6 Flavahan NA, Slifman NR, Gleich GJ, Vanhoutte PM: Human eosinophil major basic protein causes hyperreactivity of respiratory smooth muscles. Am Rev Respir Dis 1988;138: 685-688.

7 Motijima S, Frigas E, Loegering DA, Gleich GJ: Toxicity of eosinophil proteins for guinea pig tracheal epithelium in vitro. Am Rev Respir Dis 1989;139:801-805.

8 Teixeira MM, Williams TJ, Hellewell PG: Mechanisms and pharmacological manipulation of eosinophil accumulation in vivo. Trends Pharmacol Sci 1995;16:418-423.

9 Sanjar S, McCabe PR, Reynolds LH: Salmeterol, a long-acting beta-2-agonist, inhibits antigen-induced bronchial eosinophil accumulation. Am Rev Respir Dis 1991;143:A755.

10 Whelan CJ, Johnson M, Vardey CJ: Comparison of the anti-inflammatory properties of formoterol, salbutamol and salmeterol in guinea pig skin and lung. Br J Pharmacol 1993;110: 613-618.
11 Twentyman OP, Finnerty J, Harris A, Palmer J, Holgate ST: Protection against allergeninduced asthma by salmeterol. Lancet 1990; 336:1338-1342.

12 Pedersen B, Dahl R, Larsen BB, Venge P: The effect of salmeterol on the early and late phase reaction to bronchial allergen and postchallenge variation in bronchial reactivity, blood eosinophils, serum eosinophil cationic protein, and serum eosinophil protein X. Allergy 1993; 48:377-382.

13 Foster PS, Hogan SP, Ramsay AJ, Matthaei KI, Young IG: Interleukin-5 deficiency abolishes eosinophilia, airways hyperreactivity and lung damage in a mouse asthma model. J Exp Med 1996;183:195-201.

14 Yukawa T, Ukena D, Kroegel C, Chanez P, Dent G, Chung KF, Barnes PJ: Beta-2-adrenoceptors on eosinophils: Binding and functional studies. Am Rev Respir Dis 1990;141:14461452.

15 Munoz NM, Vita AJ, Neeley SP, McAllister K, Spaethe SM, White SR, Leff AR: Beta-adrenergic modulation of formyl-methionyl-leucylphenylalanine-stimulated secretion of eosinophil peroxidase and leukotriene $\mathrm{C}_{4}$. J Pharmacol Exp Ther 1994;268:139-143.

16 Koenderman L, Maikoe T, Warringa R: Signal transduction routes involved in eosinophil chemotaxis. FASEB J 1992;6:A1402.

17 Teixeira MM, Rossi AG, Giembycz MA, Hellewell PG: Effect of agents which elevate cyclic AMP on eosinophil homotypic aggregation. $\mathrm{Br}$ J Pharmacol 1996;118:2099-2106.

18 Ezeamuzie CI, Al-Hage M: Differential effects of salbutamol and salmeterol on human eosinophil responses. J Pharmacol Exp Ther 1998; $284: 25-31$.
19 Kroegel C, Yukawa T, Dent G, Venge P, Chung KF, Barnes PJ: Stimulation of degranulation from eosinophils by platelet-activating factor. J Immunol 1989;142:3518-3526.

20 Sedgwick JB, Vrtis RF, Gourley MF, Busse WW: Stimulus-dependent differences in superoxide anion generation by normal human eosinophils and neutrophils. J Allergy Clin Immunol 1988;81:876-883.

21 Teixeira MM, Hellewell PG: Evidence that eosinophil is a cellular target for the inhibitory action of salmeterol on eosinophil recruitment in vivo. Eur J Pharmacol 1997;323:255-260.

22 Sweatman WJF, Brandon DR, Cranstone S, Gooderham R, Walker JR: Indium-111-radiolabeled guinea pig peripheral leukocytes: In vitro distribution and response and response to leukotriene $\mathrm{B}_{4}$. J Pharmacol Methods 1987;18: 227-237.

23 Chan CC, McKee K, Tagari P, Chee P, FordHutchinson A: Eosinophil-eicosanoid interactions: Inhibition of eosinophil chemotaxis in vivo by an $\mathrm{LTD}_{4}$-receptor antagonist. Eur J Pharmacol 1990;191:273-280.

24 Faccioli LH, Nourshargh S, Moqbel R, Williams FM, Sehmi R, Kay AB, Williams TJ: The accumulation of ${ }^{111} \mathrm{In}$-eosinophils induced by inflammatory mediators in vivo. Immunology 1991;73:222-227.

25 Kita H, Abu-Ghazaleh RI, Gleich GJ, Abraham RT: Regulation of Ig-induced eosinophil degranulation by adenosine 3',5'-cyclic monophosphate. J Immunol 1991;146:2712-2718. 